\title{
Ethical leadership in English language education
}

\author{
Reflective accounts
}

\author{
Sahril Nur \\ English Department \\ Facultiy of Languages and Literature \\ Universitas Negeri Makassar \\ Makassar, Indonesia \\ sahrilfbsunm@unm.ac.id
}

\author{
Amirullah Abduh \\ English Department \\ Facultiy of Languages and Literature \\ Universitas Negeri Makassar \\ Makassar, Indonesia \\ amirullah@unm.ac.id
}

\author{
Rosmaladewi \\ Politeknik Pertanian Negeri Pangkep \\ Pangkep, South Sulawesi \\ Indonesia
}

\begin{abstract}
The objectives of this research were (1) to find out current leaders' perspectives of ethical leadership, and (2) to find out leaders' responses to the characteristics of ethical leadership in English language education setting. This an in-depth qualitative study of three leaders employed semi-structured interviews. The data on ethical leadership were analyzed using thematic approach. The results of the research showed that: (1) ethical leadership was concerned with underpinning beliefs that drives the leadership; (2) the key characteristics of ethical leadership were the integrated realization of values, ideology and philosophy within practices. The implication of this research was that leaders within similar contexts can learn and benefit from this study and guide them through their practices
\end{abstract}

\section{Keywords-learning outcomes; mastery learning strategy}

\section{INTRODUCTION}

Research in the area of ethical leadership is a major interest among leaders, scholars and researchers. Many authors are aware that ethical leadership can direct leaders to make right decision [1], model behavior for followers [2], become basis for moral values for members and leaders [3], influence self-efficacy and performance of managers and members [4], and impact on leaders personality traits and employee voice behavior [5]. Following the global awareness of the importance of ethical leadership, many educational institutions in Asian countries including Indonesia perceive that ethical leadership can assist leaders to create learning organizations.

This study was informed the social perspectives of ethical leadership [6]. Ethical leaders "frequently communicate with their followers about ethics, set clear ethical standards and use rewards and punishments to see that those standards are followed. Ethical leaders do not just talk a good game - they practice what they preach and are proactive role models for ethical conduct" [7, p. 579]

Brown and Treviño (2006) provided three generic characteristics of ethical leadership: transformative, authentic and future oriented [7]. Also, Avey, Palanski, \& Walumbwa (2011) claimed that ethical leadership becomes a model for follower behaviours [2]. Furthermore, Messick, \& Bazerman (1996) commented that ethical leadership essentially influenced the decision making in an oragnisation [1]. Authors above signalled that ethical leadership influenced the way people produce decision making, the social behaviors of followers, and transformed people in their organisation.

In Indonesia, ethical leadership has become one of the important issues to debate among researchers. In our observations, no specific publication relating to the ethical leadership within English language education setting. As a result, very little information was found in relation ethical leadership within this context. Furthermore, as educators and researchers in the field of language education, we have both personal and professional motivation in that this research contributes to better understanding and better practice of ethical leadership within institution, community and national levels. Therefore, the aim of this study was to address two important questions: a) what are the leaders' perceptions of ethical leadership; and b) what are the key characteristics of ethical leadership? This research contributes to growing body of literature that examines the ethical leadership and its characteristics within the context of English language education both nationally and globally.

\section{RESEARCH METHOD}

The research design for this study was a qualitative design which is reflective accounts. This reflective account was taken from three important and influential leaders in an English language education department in an Indonesian university. This purposive sampling was based on the criteria: a) hold current or former position of leadership at English department; b) possess doctoral qualifications; c) have future visions of the department.

Initially, 10 leaders were targeted in this study. However, only three leaders were interviewed in English which lasted 30-45 minutes for each participant because they represented the voices of other leaders. Two males aged between 30 s and $50 \mathrm{~s}$, while one female aged $40 \mathrm{~s}$. All of them were doctoral graduates. The data were coded and analyzed through thematic analysis [8]. Data from the findings were presented into two broad themes presented leaders' perceptions of ethical leadership and the key characteristics of ethical leadership. 


\section{RESULTS AND DISCUSSION}

Ethical leadership is "the leadership who have philosophy, ideology and purposes for the lives of members within an organization" (Male Leader A). He further described the key characteristics: "understand culture of own and others - the ability to stand which one is the right thing to do on own and which is not acceptable in other culture; future vision planned and imagined set of activities that benefits its members; sincerity - doing things not for the sake of own but it is part of the worship to deity; and take a risk - there is always white, grey, and black areas in any decision" (Male Leader A). The reasons why ethical leadership is important for English language education was due to "it will help him or her to be consistent any decision he has made and portray who the leader is" (Male Leader A).

The second leader participant in this study argued that ethical leadership is concerned with the "ability to facilitate all the need of its members, updated with the new technology, and to be aware of similarities and differences" (Male Leader B). He commented on the key characteristics: "firmed - to obey by members of followers; consistency - to maintain credibility; sincerity - to avoid the hopeless; ICT literate - all leaders have to possess because knowledge spread through ICT; intercultural awareness - to aware, and understand people from other cultures than our own; and wise - to be provide flexibility in leadership and not to rigid (Male Leader B). The reason why an ethical leadership is paramount in English language education is that it becomes' basic guide and principle for a leader in performing and implementing task and responsibility" (Male Leader B).

In addition, ethical leadership related to "a leader who is responsible to maintain and control its members and his own responsibility, and the social welfare of the members" (Female Leader C). She further elaborated the key principles of ethical leadership including "democratic, visionary, decision maker, risk taking and sensitive to problems and issues encountered by members and others". She provided the reasons for each key principles of ethical leadership.

Democratic means listen to colleagues and members; visionary relates to the initiative and ideas that leads an activity; decision maker deals with the ability to receive input from others conveying it into the right decision; risk taking relates to the braveness to try new things for improvement; and sensitive is associated with the caring of all kinds of issues and problems happening in the workplace (Female Leader C).

The reason is that ethical leadership can "help someone to be firmed and wise at any decision that focus on the welfare of its members" (Female Leader C). It appears that the findings of this study reflect what Brown, Treviño, \& Harrison (2005) argued as ethical leaders become role models for their followers. Ethical leaders have to possessed democratic, transformatic and future vision for their members. In addition, ethical leaders have the underpinning values, beliefs and ideology.

\section{CONCLUSION}

The analysis portrays that ethical leadership values should be embedded within the soul of a leader so that they can perform their duties both ethically and acceptable by its members. The core elements of ethical leadership were the portraits of leader's views within English language education setting. The study suggests that there is a need to have more comprehensive set of policy that can become an 'umbrella' of the higher education institutions. The overarching framework will help the flexibility and the direction of the future views of ethical leadership research within English language education environment.

\section{REFERENCES}

[1] D. Messick and M. Bazerman, "Ethical leadership and the psychology of decision making," MIT Sloan Manag. Rev., 1996.

[2] J. Avey, M. Palanski, and F. Walumbwa, "When leadership goes unnoticed: The moderating role of follower self-esteem on the relationship between ethical leadership and follower behavior," J. Bus. Ethics, 2011.

[3] L. Trevino, L. Hartman, and M. Brown, "Moral person and moral manager: How executives develop a reputation for ethical leadership," Calif. Manage. Rev., 2000.

[4] F. Walumbwa, D. Mayer, P. Wang, and H. Wang, "Linking ethical leadership to employee performance: The roles of leader-member exchange, self-efficacy, and organizational identification," Behav. Hum. ..., 2011.

[5] F. Walumbwa and J. Schaubroeck, "Leader personality traits and employee voice behavior: mediating roles of ethical leadership and work group psychological safety.," J. Appl. Psychol., 2009.

[6] M. Brown, L. Treviño, and D. Harrison, "Ethical leadership: A social learning perspective for construct development and testing," Organ. Behav. Hum., 2005.

[7] M. Brown and L. Treviño, "Ethical leadership: A review and future directions," Leadersh. Q., p. 579, 2006.

[8] V. Braun and V. Clarke, "Using thematic analysis in psychology," Qual. Res. Psychol., vol. 3, no. May 2015, pp. 77-101, 2006. 